\title{
Kuzey Kafkasya Sosyoekonomik Yapısının Kümeleme ve Çok Kriterli Karar Verme Yöntemleri ile Analizi
}

\author{
Ayșenur ŞIMSSEK ${ }^{1}$, Selen AVCI ${ }^{2}$, Burcu ÖZCAN ${ }^{3}$ ve Zerrin ALADA $\breve{G}^{4}$
}

Öz

Bu çalışmada coğrafi güzelliğinin ve kültürel zenginliğinin yanı sıra, önemli bir jeopolitik konuma ve ekonomik potansiyele sahip olan Kuzey Kafkasya bölgesinin sosyoekonomik yapısı incelenmiştir. Çalışmanın amacı, bölge üzerinde iyileştirmeler ve yatırım yapmak isteyen girişimcilere ve doğabilecek yeni iş fikirlerine yön vermek adına Kuzey Kafkasya bölgesinin genel durumunu tanıtmak ve sosyoekonomik haritasını çıkarmaktır. Bu amaç doğrultusunda bölgeler, belirlenen sosyal ve ekonomik kriterler esas alınarak K-Ortalamalar Algoritması aracıllğıyla kümelendirilmiştir. Sonrasında bölgeler sosyoekonomik gelişmişlik seviyelerine göre Çok Kriterli Karar Verme (ÇKKV) yöntemlerinden olan Analitik Hiyerarşi Prosesi (AHP) ve VIKOR yöntemleri ile sıralanmıştır. Çalışma bulgularına ek olarak; Adıgey Cumhuriyeti'nin sosyoekonomik durumu SWOT (Strengths-Güçlü, Weaknesses-Zayıf, Opportunities-Fırsat, Threats-Tehdit) analiziyle incelenmiş ve sonuçlar çeşitli stratejilerle desteklenmiştir.

Anabtar Kelimeler: Kuzey Kafkasya, Sosyoekonomik Yap1, Kümeleme Analizi, AHP, VIKOR

\section{Analysis of the North Caucasus Socioeconomic Structure by Clustering and MCDM Methods}

\section{Abstract}

In this study, besides its geographical beauty and cultural richness, the socioeconomic structure of the North Caucasus regions, which have an important geopolitical location and economic potential was examined. The purpose of the study is to map the socioeconomic status of the region in order to introduce the general condition of the regions and provide ideas for new business ideas, improvements and initiatives that may arise in the regions. For this purpose, firstly, the region was clustered using the K-Means Algorithm in line with the determined social and economic criteria. Afterwards, regions are sorted by Analytical Hierarchy Process (AHP) and VIKOR methods, which are among the Multiple Criteria Decision Making (MCDM) methods according to their socioeconomic development levels. In addition to the findings of the study, Socioeconomic status of Adygea Republic was analyzed with SWOT (Strengths, Weaknesses, Opportunities, Threats) analysis and results were supported with various strategies

Key Words: North Caucasus, Socioeconomic Structure, Cluster Analysis, AHP, VIKOR

\section{Atıf İçin / Please Cite As:}

Şimşek, A., Avcı, S., Özcan, B. ve Aladağ, Z. (2021). Kuzey Kafkasya sosyoekonomik yapısının kümeleme ve çok kriterli karar verme yöntemleri ile analizi. Manas Sosyal Araștırmalar Dergisi, 10(1), 295-310.

Geliş Tarihi / Received Date: 06.10.2020

Kabul Tarihi / Accepted Date: 02.01.2021

\footnotetext{
${ }^{1}$ Lisans Öğrencisi - Kocaeli Üniversitesi Mühendislik Fakültesi, aysenurs749@gmail.com

(iD) ORCID: 0000-0001-9554-7276

2 Arş. Gör. - Kocaeli Üniversitesi Mühendislik Fakültesi, selen.avci@kocaeli.edu.tr

(iD ORCID: 0000-0001-7433-5696

${ }^{3}$ Dr. Öğr. Üyesi - Kocaeli Üniversitesi Mühendislik Fakültesi, burcu.ozcan@kocaeli.edu.tr

(iD) ORCID: 0000-0003-0820-4238

${ }^{4}$ Prof. Dr. - Kocaeli Üniversitesi Mühendislik Fakültesi, zaladag@kocaeli.edu.tr

iD ORCID: 0000-0002-5986-7210
} 


\section{Giriş}

Kuzey Kafkasya tarih boyunca; önemli ticaret yollarının üzerinde bulunması, jeostratejik açıdan Orta Asya ve Batı pazarlarının giriş kapısı konumunda olması, sahip olduğu ekonomik potansiyel, topraklarında yaşayan halkların oluşturduğu kültürel zenginlik ve bozulmamış doğa güzelliği ile dikkat çekmiştir. Kafkasya, Orta Asya ile Avrupa arasında bir köprü durumundandır. Ayrıca, Hazar Denizi ve Karadeniz'e kıyısı bulunmaktadır. Rusya'nın stratejik çıkarları açısından önemli bir bölgedir (Yanar, 2002, s. 20). Rusya, kendisi için ciddi jeostratejik önem arz eden bu bölgelere hâkim olma hedefini gerçekleștirmeye 18. yüzyılda Güney Kafkasya'yı egemenliği altına alarak başlamıştır (Özbay, 1999, s. 72). Kuzey Kafkasya için ise yıllarca süren direniş ve kanlı savaşlar, nüfusunun büyük bir kısmının dünyanın dört bir yanına sürülmesi ve kalan bölge halkının da Rusya'ya teslim olmasıyla sonlanmıştır.

Kuzey Kafkasya Federal Bölgesi, Şekil 1'de görüldüğü üzere çeşitli birimlerden oluşmaktadır. Kuzey Kafkasya'da yer alan ve kısmi özerkliğe kavuşmuş olan ülkeler; Kabartay-Balkar, Karaçay-Çerkes, Çeçenistan, Dağistan, Kuzey Osetya ve İnguşetya olarak sıralanabilir (Kocalar, Üstün ve Alan, 2018, s.153). Güney Federal Bölgesinde yer alan Adıgey ve Kalmukya ile Kray statüsünde olan Stavropol ve Krasnodar dâhil olmak üzere bölgedeki on idari birim çalısma kapsamına alınmıştır.

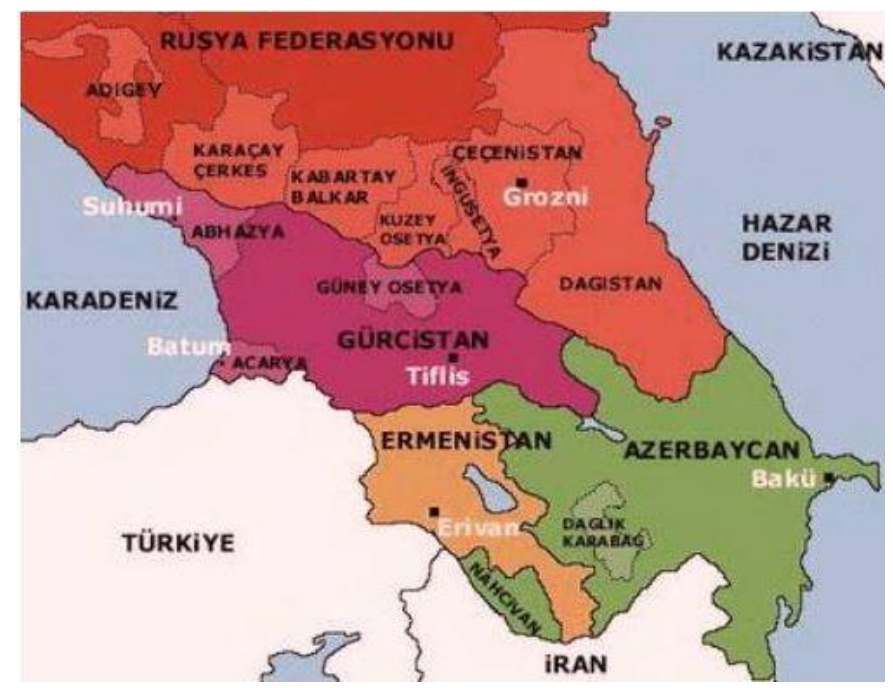

Şekil 1. Kuzey Kafkasya Haritası (Ajans Kafkas, 2008)

Kabartay - Balkar Cumhuriyeti, Terek Irmağının havzasında, Kafkas Dağlarının eteklerinde yer almaktadır. Yüz ölçümü $13.000 \mathrm{~km}^{2}$ dir. Arazisinin neredeyse yarısını pınarlar, mineral kaynaklar ve ormanlık alanlarıyla zengin dağlar oluşturmaktadır. Toprakları tarım için verimlidir. Bölge, dünyanın en zengin molibden ve tungsten cevheri depozitlerini işletmekte olup kurşun, bakır, kalay, altın, demir cevherleri, petrol, linyit kömürü ve diğer yer altı kaynaklarınca zengindir. Ülkede tungsten ve molibden işleyen fabrikalar, makine imalatı, inşaat malzemeleri imalatı, kimya endüstrisi, gıda, kereste ve hafif endüstriler de faaliyettedir. Tarım alanında ise buğday, mısır, meyve sebze yetiştiriciliği, bağcllık; koyun domuz, at çiftliği ve arıcllk önde gelir. Dağ turizmi de bölgenin önemli faaliyet alanlarından biridir (Kuzey Kafkasya Bölgesi Devlet İstatistik Servisi, 2019). Karaçay - Çerkes Cumhuriyeti, Kabartay - Balkar, Stavropol ve Krasnodar bölgeleri ile sınır komşusu olup, yüzölçümü 14.000 km²'dir. Bölge ekonomisinde hayvancılık başta olmak üzere arıcılık ve tarım yaygındır. Özellikle çevre bölgelerin patates ihtiyacının önemli bir kısmı buradan karşılanır. Ayrıca bölgede birçok göl ve mineral kaynak bulunmaktadır. Yer altı kaynakları arasında kömür, mermer, granit, altın, gümüş, alçı taşı ve demir cevheri önemlidir. Bölge, av ve dağ turizmi için de elverişlidir (Topçu, 2006, s. 3).

Adıgey Cumhuriyeti, Kafkas dağlarının kuzeyinde Krasnodar Krayı içerisinde yer alır. Yüz ölçümü $8.000 \mathrm{~km}^{2}$ 'dir. Verimli topraklara ve zengin ormanlara sahiptir. Başlica ekonomi kaynakları petrol ve doğalgaz rezervleridir (Fuat, 2015). Makine imalatı, kereste ve hafif sanayi kolları faaliyettedir. Tarım alanında hububat, şeker pancarı, tütün, ayçiçeği, mısır yetiştiriciliği önde gelirken; hayvancilıkta kümes hayvanları, arıcılık ve sığırcılıkla ilgilenilmektedir. Bölge, termal tesis ve kaplıcalar yönünden de zengindir (https://stavstat.gks.ru/Erişim tarihi: Haziran, 2020).

Kuzey Osetya, Daryal Geçidi’nin kuzey ağzında bulunmaktadır ve yüz ölçümü 8.000 km²'dir. Ekonomisi hayvancılık ve tarıma dayanır. Madencilik, makine imalatı, kerestecilik, el dokumacıllğı, cam 
üretimi gibi hafif endüstri faaliyetleri de görülür. Tarımda buğday, mısır, patates, kenevir, şeker kamış1, meyve sebze üretimi; hayvancilıkta ise sığır ve koyun besiciliği başta gelir. Süt ve süt ürünleri faaliyetleri de ekonomisinde önemli yer tutar (Fuat, 2015).

Stavropol Krayı, 4.000 metreye ulaşan Dombay-Ülgen dağlık bölgesinden başlayarak Manıç ve Hazar çöküntülerinin oluşturduğu ovalara dek uzanır. Yüzölçümü $66.000 \mathrm{~km}^{2}$ 'dir. Engebeli bir yerleşime ve sert karasal iklime sahiptir. Bölgenin düzlük alanları tarıma elverişlidir. Çiftçilik, hayvancılık ve balıkçlık önemli ekonomik faaliyetleri arasinda yer alır.

Krasnodar Krayı'nda, Krasnodar dışında Soçi, Novorossiysk, Tuapse, Anapa ve Gelencik kentleri de bulunur. Yüz ölçümü $76.000 \mathrm{~km}^{2}$ 'dir. Güneydeki dağlık kesimler dışında bölge tarıma elverişlidir. Arpa, buğday, mısır gibi ürünlerin yanında, Kuban civarlarında pirinç de yetiştirilir. Kuban Irmağı kesimleri tarım ürünleri çeşitliliği bakımından zengindir. Hayvancılıkta, sığır, domuz ve kümes hayvanlarının yanı sıra arıcilık ve deniz-tatlı su balıkçılığı da faaliyettedir. Bölgede doğalgaz ve petrol çıkarılır ve önemli doğalgaz ve petrol ihraç limanları da bulunmaktadır. Ayrıca orman ve tarım ürünlerini işleyen sanayilere de sahiptir.

İnguşetya, Kafkasya'nın güney taraflarında yer alır. Küçük bir bölge olmasına rağmen doğal kaynaklarıyla ve zengin bitki örtüsüyle önem taşır. Çeçenistan'a komşu olan İnguşetya, petrol kaynakları yönünden de zengindir. Ayrıca mermer, alçı, dolomit taşı, granit, jeotermal enerji, kireçtaşı ve doğalgaz rezervleri bakımından zengindir.

Dağıstan Cumhuriyeti, yüzölçümü ve nüfus bakımından Kafkas cumhuriyetleri arasında en büyük cumhuriyettir. Rusya'nın etnik çeşitliliğe sahip en zengin bölgesi olan Dağıstan'da otuzdan fazla yerli halkın yaşadığı belirtilmektedir (Uyar, 2018, s. 219). Bölge, Avrupa ve Rusya’yı doğuya bağlayan avantajlı konuma sahiptir. Dağıstan ekonomisi; endüstri, tarım, gıda, yapı malzemeleri, tüketim malları ve sanat ürünlerinin yanı sıra makina üretimi, petrol çıkarımı, alet yapımı, kimya ve enerji üretimi alanında gelişmiştir. Yavaş seyirde olsa da ulusal ekonominin durumu giderek gelişmektedir (Kafiad, 2020).

Çeçenistan, doğu ve kuzeyinde Dağıstan, batıda İnguşetya ve güneyde Gürcistan ile komşu olup başkenti Groznidir. Petrol-gaz üretimi ve arıtımı, mühendislik, işleme ve gida endüstrileri, tarım, yap1 malzemeleri endüstrisi gibi alanlarda faaliyettedir (Kafiad, 2020). Kalmukya, güneybatıda Stavropol Bölgesi, kuzeybatıda Volgograd Bölgesi, batıda Rostov Bölgesi ve doğuda Astrahan Bölgesi ile sınır komşusudur. Başkenti Elista şehridir. Çeşitli hidrokarbon rezervlerine, petrol ve doğal gaz yataklarına sahiptir (Mikail, 2016).

Gürbüz ve Karabulut (2008, s. 32-34) Sovyet Sosyalist Cumhuriyetler Birliği’nin (SSCB) dağılmasıyla ortaya çıan ülkelerde ortalama yaşam süresi ile sosyoekonomik değişkenler arasındaki ilişkiyi incelemiştir. Ülkeler arasındaki ortalama yaşam benzerliklerini ortaya koymak için Hiyerarşik Kümeleme Analizi kullanılmıştır. Değişkenler; ortalama yaşam süresi, nüfus, nüfus artış hızı, doğum oranı, çocuk ölüm oranı, 0-14 ve +65 yaş nüfus oranı, şehir nüfus oran1, okuryazar oranı, enflasyon, işsizlik oranı, tarımda sanayide, hizmette ve ticarette çalışanların toplam istihdama oranı, ihracat, ithalat, ihracatın ithalatı karşılama oranı, kişi başına enerji tüketimi ve sağlık harcamaları, 1 yaşın altındaki çocuklarda kızamık aşısı aşılama oranı, 5 yaş altı ölüm oranı, insani gelişmişlik indeksi, milli gelirden eğitime ayrılan pay, eğitim endeksi, kişi başına milli gelir, milli gelir, milli gelir endeksi, satın alma gücüne göre milli gelir, satın alma gücüne göre kişi başına milli gelir, HIV virüsü taşıyanların oranı, 15-64 yaş HIV virüsü taşıma oranı, doktor sayısı, çalışan kadın sayısı, su kaynaklarına ulaşabilme oranı ve içme suyu temin oranı olarak seçilmiştir. İkili değişkenler arasındaki ilişkinin yönünü ve gücünü analiz etmek için korelasyon analizi uygulanmıştır. "Ortalama yaşam süresi” bağımlı değişken olarak seçilmiş olup bu değişken ile diğer değişkenler arasında fonksiyonel bir ilişki olup olmadığının tespit edilmesi için ise doğrusal regresyon modelleri kurulmuştur.

Sandal (2009, s. 89-92); Türkiye, Doğu Avrupa ve Kafkas ülkelerinin 1995-2005 y1lları arasında göstermiş olduğu gelişmeleri 21 sosyoekonomik kriter altında Hiyerarşik Küme Analizi ile incelemiştir. Kriterler; ortalama yaşam süresi, toplam milli gelir, kişi başına milli gelir, milli gelirden eğitime, halk sağlığına, enerji tüketimine ayrılan pay, kişi başına elektrik tüketimi, bebek ve çocuk ölüm oranı, doktor sayısı, yılllk nüfus artış oranı, şehir nüfusu oranı, 15 yaş altı ve 65 yaş üstü nüfus oranı, kadın başına doğum sayısı, işsizlik oranının toplam işgücüne oranı, ekonomide çalışan kadın oranının çalışma çağındaki kadınlara oranı, en fakir ve en zengin nüfus oranının milli gelirden aldığı pay, cep telefonu sayısı ve 15 yaş üstü okuryazar oranı olarak seçilmiştir. Gürbüz ve Karabulut (2009, s. 30-34, 45), Gürbüz ve Karabulut (2008)'de sıralanan 36 sosyoekonomik değişkeni kullanarak SSCB'nin dağılmasıyla bağımsız olan 15 ülke 
arasındaki benzerlikleri tespit etmek için Hiyerarşik Küme Analizi uygulamıştır. Sonuç olarak; Baltık, Doğu Avrupa, Kafkas ve Orta Asya ülkelerinin kendi içlerinde birbirlerine daha çok benzediği görülmüştür.

Açma ve Yenişen $(2013$, s. 131, 140, 147, 148) Kuzey ve Güney Kafkasya bölgelerinin ekonomik potansiyelini, faaliyetlerini ve bölgelerin ekonomik süreçlerini açıkladıkları çalışmalarında, ekonomik değişim ve dönüşümün oluşturulması için çeşitli stratejiler önermişlerdir. Sukhovskaya (2013, s. 224) Kuzey Kafkasya'da sürdürülebilir kalkınmanın kilit bir faktörü olarak kırsal alanların kalkınmasına ilişkin sorunları analiz etmiştir. Bu bağlamda, kırsal turizm faaliyetlerinin ilkeleri, tarım ve eko-turizmin oluşumu ve gelişimini etkileyen faktörler incelenmiştir. Çalışmada, bölgedeki turizm endüstrisinin özellikleri de verilmektedir. Gerasimov, Gromov, Levchenko, Grigorieva ve Oboturova (2014, s. 699), Kuzey Kafkasya'nın durumunu araştırmak için çok boyutlu ve bütünsel bir yaklaşım önermişlerdir. Bölgelerin mevcut seviyesini (oldukça gelişmiş, orta derecede gelişmiş, gelişmekte olan ve az gelişmiş) ve sosyoekonomik gelişme oranını (güçlü, orta ve göze çarpan) nitel olarak tanımlamışlardır. Amirova (2015, s. 160-162), Kuzey Kafkasya bölgelerinin sosyoekonomik gelişmişlik düzeylerinin bölgesel farklılıklarını etkileyen faktörleri incelemiş ve sürdürülebilir ekonomik büyümesini sağlamak için çeşitli stratejiler önermiştir.

Holland (2016, s. 50) Rusya'nın Kuzey Kafkasya'nın ekonomik durumuna yönelik "strateji"sini incelemiştir. Bölgenin "strateji"de tanımlanan bazı büyüme alanlarında son beş yılda ilerleme kaydetmiş olduğunu belirtmiş ancak bölge ekonomisinin uzun vadeli yaşayabilirliğini sorgulamıştır. Kuzey Kafkasya'nın turizm, tarım potansiyeline ve bölgedeki petrol ve gaz üretimine dikkat çekmiştir. Magomedovich (2017, s. 48, 54), Kuzey Kafkasya Federal Bölgesinin sosyoekonomik durumunu, pazar eğilimlerini ve demografik süreçlerinin özelliklerini incelemiştir. Çalışma bulgularında, iş gücü piyasasının sıkıntılarını ve yüksek işsizliği yüksek nüfus artışıla ilişkilendirmiştir. Akinin, Akinina, Alimova, Viderker ve Ter-Akopov (2016, s. 200), Kuzey Kafkasya bölgesinin sosyoekonomik ve mali kalkınmasının mevcut jeopolitik durumda federal bölge sınırları içindeki önceliklerini belirlemiştir. Araştırmada istatistiksel, monografik, sosyolojik yöntemler ve mantıksal modelleme kullanılmıştır.

Kolosov vd. (2017, s. 259, 269, 270) Kuzey Kafkasya bölgelerini geliştirmeye yönelik faaliyetlerin ve uygulanan reformların sonuçlarını değerlendirmiştir. Makalede ele alınan ana konular Kuzey Kafkasya için kalkınma stratejileri, yatırım projeleri, iç kalkınma kaynakları (bölgesel bütçeler ve gölge ekonomi), arazi sorunu, belediye reformu ve yerel kalkınmadır. Larionova vd. (2018, s. 1) çalışmalarında, Kuzey Kafkasya turizm endüstrisinde yatırım potansiyelini engelleyen faktörleri vurgulamış ve yatırımların artması için çeşitli stratejiler önermiştir. Çalışmada; uzman değerlendirmeleri, ekonomik ve istatistiksel analiz yöntemleri kullanılmıştr. Rusya Federal Devlet İstatistik Servisi'nin 2012-2016 yılları verileri kullanılarak Kuzey Kafkasya'nın yatırım potansiyeli tahminlenmiştir.

$\mathrm{Bu}$ çalşmanın amacı sosyoekonomik potansiyele sahip ve doğal kaynaklar bakımından gelecek vadeden Kuzey Kafkasya'da yer alan on bölgenin kayıtlı verilerinin bilimsel metotlarla analiz edilmesi ve bölgedeki sosyoekonomik firsatlar için bir projeksiyon sunulmasıdır. Sosyal açıdan, "Demografi ve Nüfus, İstihdam-İşsizlik, Nüfusun Gelir ve Giderleri, Sağlık, Eğitim-Formasyon, Ücretli Servisler, Yaşam Standartları"; ekonomik açıdan, "Brüt Bölgesel Ürün, Endüstriyel Üretim, Fiyatlar, Yatırım-İnşaat, Dış Ticaret ve Tarım" kriterleri kullanılarak kümeleme analizi yapılmış ve benzer özellikler taşıyan bölge kümeleri belirlenmiştir. Sonrasında, Çok Kriterli Karar Verme (ÇKKV) yöntemlerinden Analitik Hiyerarşi Prosesi (AHP) ve VIKOR yöntemleri ile bölgeler sıralanmıştır. Son olarak, Adıgey Cumhuriyeti için SWOT analizi yapılarak bölge firsatlarına yönelik önerilerde bulunulmuştur. Böylece Kuzey Kafkasya'nın sosyal ve ekonomik boyutu detaylı incelenmiş, yatırım firsatları için en uygun bölgenin seçimi konusunda Kümeleme Analizi ve ÇKKV yöntemleri kullanılarak girişimcilere yön vermek ile literatüre katkıda bulunmak amaçlanmıştır.

\section{Yöntem}

Çalışma üç aşamadan oluşmaktadır. Birinci aşamada, sosyoekonomik gösterge verilerine dayalı kümeleme analizi ile benzer özellikler taşıyan bölge kümeleri belirlenmiştir. İkinci aşama, Analitik Hiyerarşi Prosesi (AHP) ve VIKOR yöntemleri ile sosyoekonomik kriterler doğrultusunda bölgelerin sıralanmas1 aşamasıdır. Son olarak, sıralamada önemli bir yere sahip olduğu tespit edilen Adıgey Cumhuriyeti için SWOT analizi yapılarak bölge firsatlarına yönelik önerilerde bulunulmuştur. Önerilen metodoloji Şekil 2'de gösterilmiştir. 


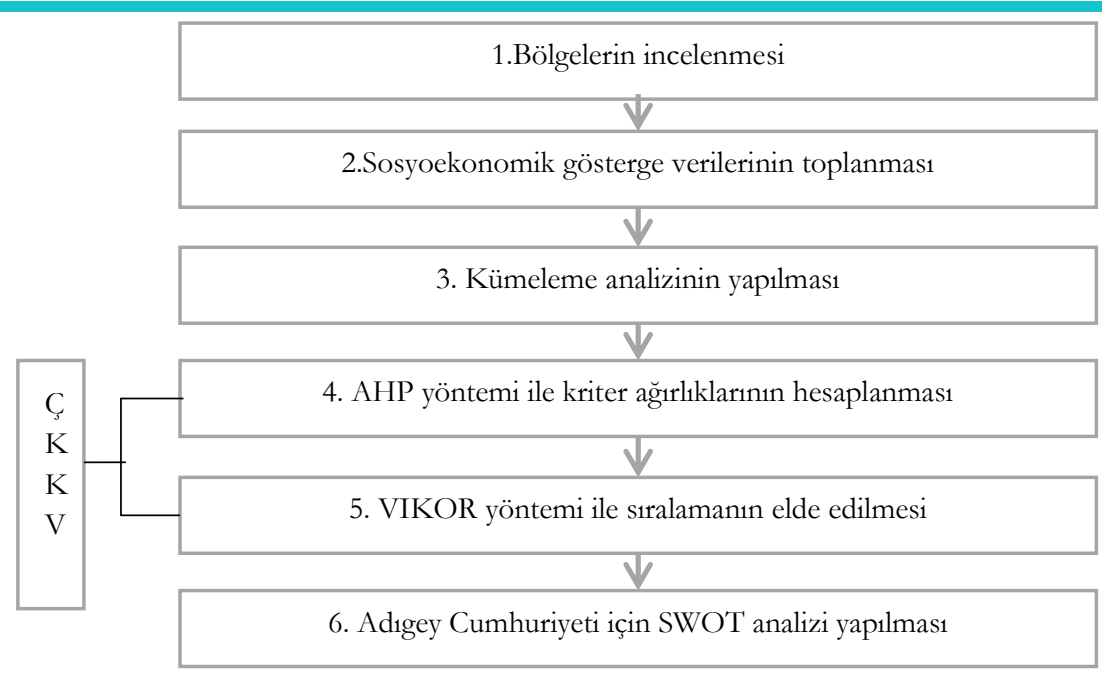

Şekil 2. Metodoloji

Bu bölümde K-Ortalamalar Kümeleme yöntemi ile AHP ve VIKOR yöntemleri alt başlıklarda kısaca açıklanmıştır.

\section{K-Ortalamalar Kümeleme Yöntemi}

Kümeleme analizi, verilerin benzerliklerine göre sinıflandırılması ve alt gruplara ayrılması için kullanılan çok değişkenli bir istatistiksel yöntemdir. Kümeleme analizinde değişkenleri mümkün olduğu kadar grup içi homojen, gruplar arası heterojen kümelere ayırmak ve bu grupların kümelenmesinde belirleyici olan değişkenleri ortaya çıkarmak amaçlanır (Yıldız, Kekezoğlu ve İşen, 2019, s. 508). KOrtalamalar yöntemi, hiyerarşik olmayan kümeleme yöntemleri arasında en sık kullanılanlardan biridir. Yöntem, bir $X$ veri setine ait $d$ adet değişkeni ve $N$ adet özellik vektörünü $C$ adet kümeye ayırarak sınıflar. Yöntemde ilk olarak, önceden belirlenen $C$ adet kümeye ait merkezler seçilir ve her bir değişken benzerlik ölçütü kullanılarak en yakın küme merkezine atanır. Her bir değişkenin bir kümeye atanmasından sonra küme merkezleri yeniden hesaplanır ve değişkenler yeni küme merkezlerine göre farklı kümelere atanabilir. Algoritma küme üyeliklerinde herhangi bir değişim olmayana dek tekrarlanır. Analiz sonucunda oluşan küme numaralarının o küme grubunun daha nitelikli ya da üstün olduğunu ifade etmediğine dikkat edilmelidir. Numaralandırmalar, oluşan küme gruplarının yığılma şeklini ve değişken girdileri doğrultusunda benzer segmentte olduklarını belirtir (Han, Kamber ve Pei, 2011, s. 451-454).

$N$ adet özellik vektörüne ve $d$ adet değişkene sahip bir $X$ veri seti $X=\left\{x_{k} \mid \mathrm{k}=1,2, \ldots . N\right\}$ şeklinde tanımlanabilir. Bu veri setinde $k$. özellik vektörü $\mathrm{x}_{\mathrm{k}}=\left[\mathrm{x}_{\mathrm{k} 1}, \mathrm{x}_{\mathrm{k} 2}, \ldots, \mathrm{x}_{\mathrm{kd}}\right], \mathrm{x}_{\mathrm{k}} \in \mathrm{R}^{\mathrm{d}}$ şeklindedir. K-Ortalamalar algoritmasında, veri seti alt kümelere ayrilırken Denklem 1'de verilen fonksiyonunun minimize edilmesi amaçlanmaktadır. Diğer bir deyişle, her bir özellik vektörü ile en yakın küme merkezi arasındaki mesafenin en küçük olması ve dolayısıyla benzer verilerin aynı kümede toplanması sağlanır. Literatürde genellikle Denklem 2'de verilen Öklid mesafe ölçütü kullanılmaktadır.

$$
J(S: X)=\sum_{i=1}^{C} \sum_{k=1}^{N} d_{i k}^{2}\left(x_{k}, s_{i}\right)
$$

Denklem 1'de verilen d $\mathrm{i}_{\mathrm{ik}}^{2}$ aşağıdaki gibi tanımlanmıştır (Fırat, Dikbaş, Koç ve Güngör, 2012, s. 6039) :

$$
\begin{aligned}
& \mathrm{d}_{\mathrm{ik}}^{2}=\left|\mathrm{x}_{\mathrm{k}}^{(\mathrm{i})}-\mathrm{s}_{\mathrm{i}}\right|^{2} \\
& \mathrm{~s}_{\mathrm{i}}=\frac{1}{\mathrm{~N}} \sum_{\mathrm{k}=1}^{\mathrm{N}} \mathrm{x}_{\mathrm{k}}^{(\mathrm{i})}
\end{aligned}
$$




\section{Analitik Hiyerarşi Prosesi (AHP)}

Analitik Hiyerarşi Prosesi (AHP), sayısal olan ve sayısal olmayan kriterlerin karşılaştırılmasını ve alternatiflerin analitik olarak değerlendirilmesini sağlayarak karar vericiye kendi karar verme mekanizmasını oluşturma imkânı veren ÇKKV tekniklerinden biridir. Karar vericinin önceliklerini, önsezilerini ve deneyimlerini karar verme sürecine mantıksal bir yaklaşımla dâhil edebilmesi nedeniyle bu yöntem karar problemlerinde sıklıkla kullanılır. Yöntemin adımları aşağıda kısaca açıklanmıştır (Gür, Hamurcu ve Eren, 2017, s. 438):

Adim 1: Kriterler ve alternatifler belirlenerek hiyerarşik yapı kurulur. oluşturulur.

Adım 2: Saaty tarafından literatüre kazandırılan skala kullanılarak ikili karşılaştırma matrisleri

Adım 3: Karşılaştırma matrisinin sütun toplamları alınır ve her değer kendi sütun toplamına bölünerek normalize edilir.

Adım 4: Karşılaştırlan öğelere dair öncelik vektörleri hesaplanır.

Adım 5: Öncelikler elde edildikten sonra, karar vericinin ikili karşılaştırmalar sırasında tutarlı olup olmadığını ölçmek için tutarlılık oranının hesaplanması gerekir. Bunun için öncelikle "Tutarlılık indeksi (CI)" hesaplanir.

Adım 6: CI değeri hesaplandıktan sonra, CI'nın rassallık indeksine (RI) oran hesaplanır ve "tutarlılık oranı (CR)" elde edilir. CR'nin 0,1'den daha az olması gerekir.

\section{VIKOR Yöntemi}

VIKOR yöntemi, birden çok kritere bağlı alternatifler arasında, hedeflenen sonuca en yakın ve en uzlaşık alternatifi seçmeye yardımcı olan ÇKKV yöntemlerinden biridir. Uzlaşımcı sıralamada, en yüksek faydayı ve minimum pişmanlığı sağlayan, ideale en yakın, uzlaşık bir çözüm elde edilir (Sennaroglu ve Varlik Celebi, 2018, s. 163). Yöntemin adımları aşağıda kısaca açıklanmıştır.

Adım 1: En iyi $\mathrm{F}_{\mathrm{i}}^{*}$ ve en kötü $\mathrm{F}_{\mathrm{i}}{ }^{-}$değerleri bulunur. Kriter maksimizasyon hedefli ise alternatiflerin o kriter için sahip olduğu en yüksek değer en iyi $\mathrm{F}_{i}^{*}$, en düşük değer ise en kötü $\mathrm{F}_{\mathrm{i}}^{-}$değeri olurken; minimizasyon hedefli bir kriter ise alternatiflerin o kriter için sahip olduğu en düşük değer en iyi $\mathrm{F}_{\mathrm{i}}^{*}$, en yüksek değer ise en kötü $\mathrm{F}_{\mathrm{i}}^{-}$değeri olacaktır (Paksoy, 2015, s. 159, 160).

Adım 2: Daha kolay işlem yapabilmek ve uzun sayı gruplarından kaçınmak adına değerler Denklem 4 kullanılarak normalize edilir.

$$
\mathrm{X}_{\text {normalize }}=\frac{\mathrm{X}-\mathrm{F}_{\mathrm{i}}^{-}}{\mathrm{F}_{\mathrm{i}}^{*}-\mathrm{F}_{\mathrm{i}}^{-}}
$$

Adım 3: Normalize edilen değerler ağırlık katsayılarıyla çarpılır.

Adım 4: Her bir alternatif için $\mathrm{S}_{\mathrm{i},}, \mathrm{R}_{\mathrm{ij}}$ ve $\mathrm{Q}_{\mathrm{ij}}$ değerleri bulunur. $\mathrm{S}_{\mathrm{ij}}$ değeri, her alternatif için kriterler değerlerinin toplamı olup Denklem 5 ile bulunur. $\mathrm{R}_{\mathrm{ij}}$ ise her alternatif için kriterlerin maksimum değeridir ve Denklem 6 ile hesaplanır.

$$
\begin{aligned}
\mathrm{S}_{\mathrm{ij}} & =\sum_{\mathrm{i}=0}^{\mathrm{n}} \mathrm{W}_{\mathrm{ij}} \frac{\mathrm{F}_{\mathrm{i}}^{*}-\mathrm{F}_{\mathrm{i}}}{\mathrm{F}_{\mathrm{i}}^{*}-\mathrm{F}_{\mathrm{i}}^{-}} \\
\mathrm{R}_{\mathrm{ij}} & =\operatorname{maks}\left[\mathrm{W}_{\mathrm{ij}} \frac{\mathrm{F}_{\mathrm{i}}^{*}-\mathrm{F}_{\mathrm{i}}}{\mathrm{F}_{\mathrm{i}}^{*}-\mathrm{F}_{\mathrm{i}}^{-}}\right]
\end{aligned}
$$

Adım 5: Denklem 7 kullanılarak $\mathrm{Q}_{\mathrm{ij}}$ değerleri hesaplanır. Qij değerleri, maksimum grup faydasını ifade eder. Formülde bulanan v değeri, maksimum grup faydasını sağlayacak strateji için ağırlık değerini; (1-v) değeri ise karşıt görüşe sahip karar vericilerin minimum pişmanlığını ifade eder. VIKOR yönteminde, maksimum grup faydasına ilişkin $\mathrm{v}>0,5$ çoğunluk tercihini, $\mathrm{v}=0,5$ uzlaşma (konsensus) değerini ve $\mathrm{v}<$ 0,5 vetoyu temsil etmektedir (Lixin, Ying ve Zhizuang, 2008, s. 1209). Bu çalışmada, çoğunluk tercihi ve uzlaşık yaklaşımla değerlendirme yapılmışır. 


$$
\begin{aligned}
& \mathrm{Q}_{\mathrm{ij}}=\frac{\mathrm{v}\left(\mathrm{S}_{\mathrm{ij}}-\mathrm{S}^{*}\right)}{\left(\mathrm{S}^{-}-\mathrm{S}^{*}\right)}+\frac{(1-\mathrm{v})\left(\mathrm{R}_{\mathrm{ij}}-\mathrm{R}^{*}\right)}{\left(\mathrm{R}^{-}-\mathrm{R}^{*}\right)} \\
& \mathrm{S}^{*}=\operatorname{minS}_{\mathrm{ij}} \quad \mathrm{S}^{-}=\mathrm{maks}_{\mathrm{ij}} \\
& \mathrm{R}^{*}=\operatorname{minR}_{\mathrm{ij}} \quad \mathrm{R}^{-}=\operatorname{maksR}_{\mathrm{ij}}
\end{aligned}
$$

Adım 6: Her alternatif için $\mathrm{S}_{\mathrm{ij}}$, $\mathrm{R}_{\mathrm{ij}}$ ve $\mathrm{Q}_{\mathrm{ij}}$ değerleri hesaplanır ve $\mathrm{Q}_{\mathrm{ij}}$ değeri küçükten büyüğe sıralanır. Elde edilen sıralamada, ilk sırada bulunan alternatifin en iyi alternatifi temsil edip etmediğine, geçerlilik testlerinin sonucuna göre karar verilir.

\section{Bulgular}

1. Bölgelerin incelenmesi: Çalışmada Kuzey Kafkasya bölgesinde yer alan Kabartay - Balkar Cumhuriyeti, Karaçay - Çerkes Cumhuriyeti, İnguşetya, Osetya, Adıgey, Stavropol, Krasnodar, Çeçenistan, Dağıstan ve Kalmukya'dan oluşan on bölge, sosyal ve ekonomik yönden detaylı olarak incelenmiştir.

2. Sosyoekonomik gösterge verilerinin toplanmasi: İncelenen veriler 2017 yll ve sonrasina ait olup her değişken grubu için aynı yllın oran ve değerlerinin ele alınmasına dikkat edilmiştir. Tablo 1'de çalışmada

\begin{tabular}{|c|c|c|}
\hline & Kriterler & Değişkenler \\
\hline \multirow{13}{*}{ Sosyal Faktörler } & \multirow{4}{*}{ Demografi ve Nüfus } & Nüfus \\
\hline & & Nüfus Artış Hızı \\
\hline & & Nüfus Yoğunluğu \\
\hline & & Kentsel Nüfus Pay1 \\
\hline & \multirow{2}{*}{ İstihdam-İşsizlik } & Çalışan Sayısı / Ekonomik Aktif Nüfus \\
\hline & & İşsizlik Oranı \\
\hline & \multirow{3}{*}{ Sağlık } & Yaşam Beklentisi \\
\hline & & Bebek Ölümleri \\
\hline & & Doktor Say1s1 \\
\hline & \multirow{2}{*}{ Eğitim-Formasyon } & Okul Öncesi Ë̆itim \\
\hline & & Yüksek Öğretim Öğrenci Sayısı \\
\hline & Ücretli Servisler & Toplam Hizmet Hacmi Endeksi \\
\hline & Yaşam Standartları & 1000 Kişi Başına Düşen Araba Sayısı \\
\hline \multirow{15}{*}{ Ekonomik Faktörler } & \multirow{3}{*}{ Mili Hasıla } & Brüt Bölgesel Ürün \\
\hline & & Perakende Ciro \\
\hline & & Kişi Başına Düşen Bölgesel Hasıla \\
\hline & Nüfusun Gelir ve Giderleri & $\begin{array}{l}\text { Kişi Başına Düşen Aylık Gelir } \\
\text { Yoksulluk Oranı }\end{array}$ \\
\hline & \multirow{3}{*}{ Endüstriyel Üretim } & Sanayi Üretim Endeksi \\
\hline & & $\begin{array}{l}\text { Maden Çıarımı } \\
\text { İmalat }\end{array}$ \\
\hline & & Elektrik Gaz ve Su Üretimi-Dağıtımı \\
\hline & Fiyatlar & Tüketici Fiyat Endeksi \\
\hline & \multirow{2}{*}{ Yatırım-İnşaat } & Sabit Kıymet Yatırımlarının Hacmi \\
\hline & & Konut İnşaatı \\
\hline & Diş Ticaret & Karşılama Oranı (İhracat/İthalat) \\
\hline & \multirow{4}{*}{ Tarım } & Tarımsal Üretim \\
\hline & & Hayvanc1lı Üretimi \\
\hline & & Mahsul Üretimi \\
\hline & & Büyükbaş ve Kümes Hayvancillğ1 \\
\hline
\end{tabular}
kullanılan sosyal ve ekonomik kriterler ve bu kriterleri etkileyen değişkenler yer almaktadır.

Tablo 1. Sosyal ve Ekonomik Kriterler 
3. Kümeleme analiz̧inin yapılması: Çalışmada, araştırmacının küme sayısını anlamlı bir şekilde belirleyebildiği K-Ortalamalar algoritmasından faydalanılmıştır. Bu algoritmayla, Kuzey Kafkasya'da yer alan 10 coğrafi bölge; bu bölgelere ait 13 sosyal ve 17 ekonomik değişken girdisiyle istatistiksel analizlere tabi tutulmuştur. Veriler, ülkelerin resmi web siteleri ve dünya veri atlası sitelerinden alınmıştır (Dünya Veri Atlas1, 2019), (Adigey Cumhuriyeti Resmi Web Sitesi, 2020), (Çeçen Cumhuriyeti Hükümeti Web Sitesi, 2020), (Kalmukya Cumhuriyeti Hükümeti Web Sitesi, 2020), (Stavropol Tarım Bakanlı̆̆1, 2020).

Şekil 3’te küme gruplarının oluşmasında değişkenlerin etkileri, güçlü değişkenden zayıf değişkene doğru görselleştirilmiştir. Brüt bölgesel ürün faktörünün kümeleme analizinde güçlü etkiyle belirleyici olduğu görülmektedir. Brüt bölgesel ürün faktörünü, bebek ölümleri ve konut inşaat izlemektedir.

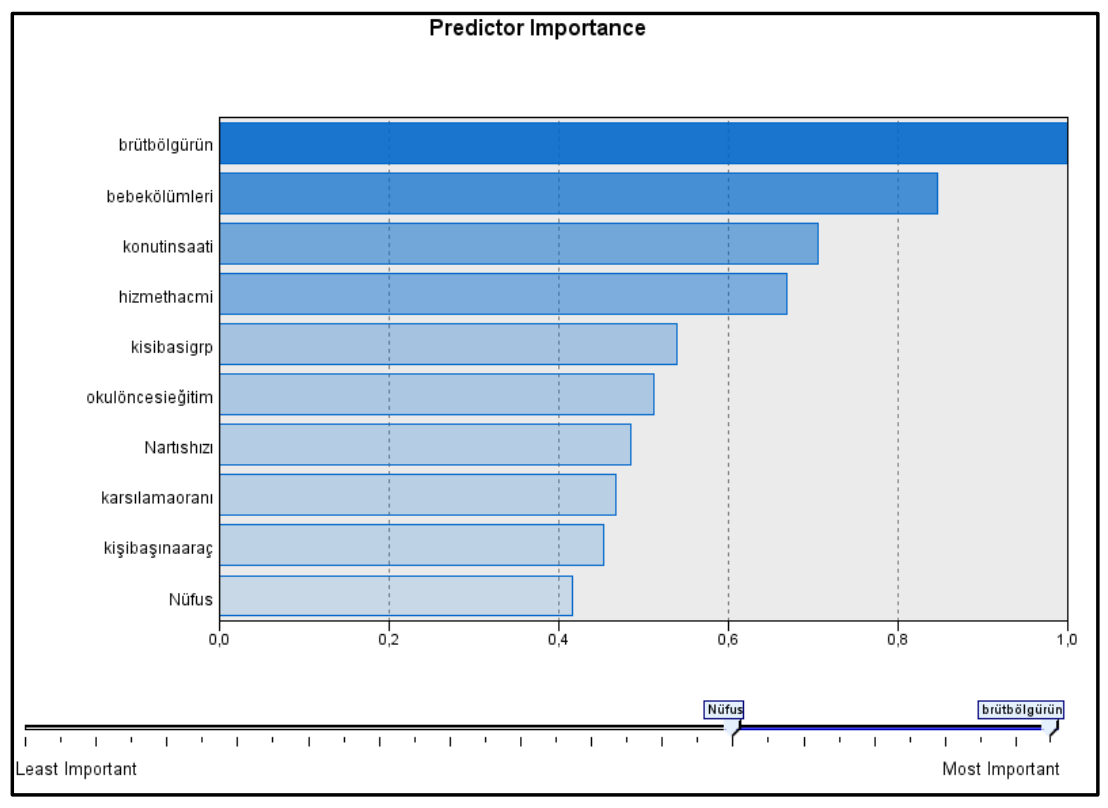

Şekil 3. Kümelenmeyi Etkileyen Faktörlerin Güclülük Dereceleri

Tablo 2'de görüldüğü üzere, kümeleme analizine göre Osetya, Adigey Cumhuriyeti, Stavropol, Kabartay - Balkar Cumhuriyeti, Karaçay Çerkes Cumhuriyeti, Çeçenistan, Dağıstan ve Kalmukya ortak bir kümede toplanmış; Krasnodar ve İnguşetya ise ayr1 birer küme oluşturmuştur. Bölgelerin sosyal ve ekonomik değişkenlerine ait veriler ve çalışmanın devamında yer alan VIKOR yönteminden elde edilen sonuçlar dikkate alındığında; sosyoekonomik açıdan en zayıf bölge olan İnguşetya'nın ve sosyoekonomik açıdan en iyi olan Krasnodar'ın ayrı birer küme oluşturması, diğer bölgelerin ise ortak bir kümede yer almaları dikkat çekici bir durumdur.

Tablo 2. Kümeleme Analiz̧ Sonuçlar

\begin{tabular}{cccc}
\hline & Bölge & Küme & Uzaklik \\
\hline 1 & Kabartay - Balkar & 1 &, 829 \\
2 & Karaçay - Çerkes & 1 &, 996 \\
3 & İnguşetya & 3 &, 000 \\
4 & Osetya & 1 & 1,490 \\
5 & Adigey & 1 & 1,209 \\
6 & Stavropol & 1 & 1,294 \\
7 & Krasnodar & 2 &, 000 \\
8 & Çeçenistan & 1 & 1,430 \\
9 & Dağıstan & 1 & 1,597 \\
10 & Kalmukya & 1 & 1,256 \\
\hline
\end{tabular}

4. Kriter ağırlıklarmm hesaplanması: Çalışmada kriter ağırlıkları AHP yöntemi ile elde edilmiştir. Sosyal açıdan, "Demografi ve Nüfus", "İstihdam-İsssizlik", "Sağlık", "Ĕğitim-Formasyon”, "Ücretli Servisler", "Yaşam Standartları"; ekonomik açıdan, "Milli Hasıla", "Nüfusun Gelir ve Giderleri”, "Endüstriyel Üretim”, "Fiyatlar", "Yatırım-İnşaat", "Dış Ticaret” ve "Tarım” kriter olarak belirlenmiştir. Böylece Şekil 4’te görüldüğü üzere hedef, kriterler ve bölgelerden oluşan alternatifler ile hiyerarşi matrisi oluşturulmuştur. 


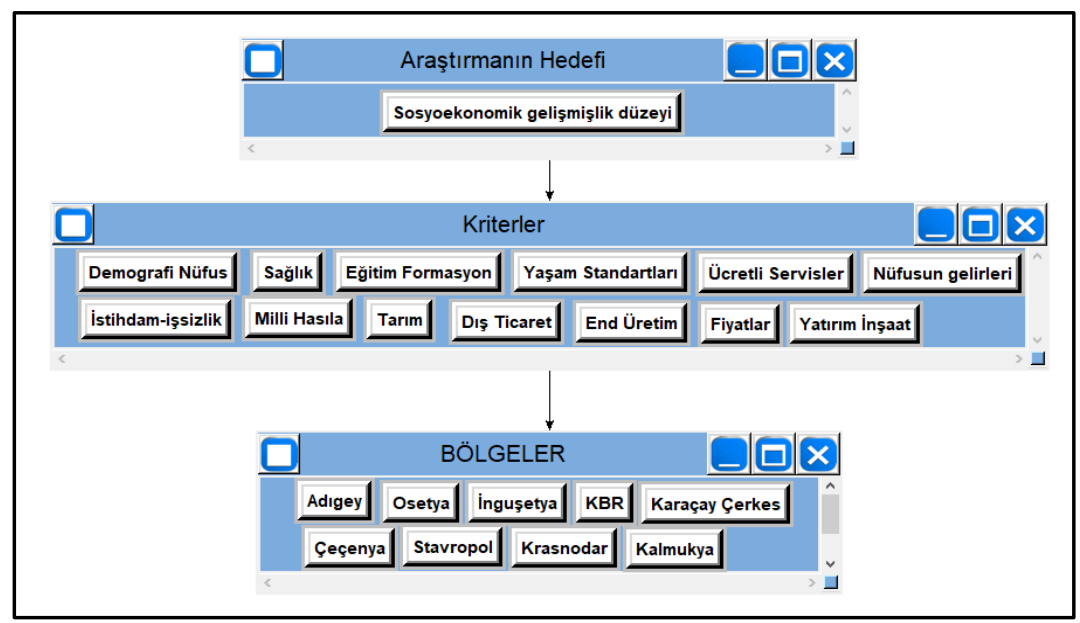

Şekil 4. Kuzey Kafkasya Cumburiyetleri Sosyoekonomik Değerlendirme Hiyerarşisi

Tablo 3'te sosyoekonomik kriterlerin ağırlık katsayıları gösterilmiş olup bu ağırlıklar VIKOR yönteminde kullanılacaktır. Tutarlılık oranı ise 0,01175 olarak hesaplanmış olup kabul edilebilir seviyededir.

Tablo 3. Sosyoekonomik Kriterlerin Ağrrlk Katsaylarn

\begin{tabular}{lc}
\hline \multicolumn{1}{c}{ Kriter } & Ağ̈rlllk \\
\hline Endüstriyel Üretim & 0,17449 \\
Milli Hasila & 0,17449 \\
Dış Ticaret & 0,11205 \\
Nüfusun Gelir ve Giderleri & 0,11205 \\
İstihdam-İssizizlik & 0,07270 \\
Fiyatlar & 0,06688 \\
Sağllk & 0,06688 \\
Tarım & 0,06688 \\
Ücretli Servisler & 0,03989 \\
Eğitim-Formasyon & 0,03852 \\
Demografi ve Nüfus & 0,02506 \\
Yatırım-İnşaat & 0,02506 \\
Yaşam Standartları & 0,02506 \\
\hline
\end{tabular}

Sosyoekonomik gelişmişliğe etki eden en önemli faktörlerin \%17’lik pay ile endüstriyel üretim ve milli hasıla olduğu belirlenmiștir. Bu kriterleri, dıș ticaret ve nüfusun gelir giderleri takip etmektedir. En düşük paya sahip olan kriterlerin ise yaşam standartları, yatırım-inşaat ve demografi ve nüfus olduğu görülmüştür.

5.VIKOR yöntemi ile siralamann elde edilmesi: Her bir kriterin yönlenmesine göre maksimize (maks) ve minimize (min) hedefler Tablo 4’te gösterildiği üzere oluşturulmuştur. 
ŞİMŞEK, AVCI, ÖZCAN ve ALADAĞ

Kuzey Kafkasya Sosyoekonomik Yapısının Kümeleme ve Çok Kriterli Karar Verme Yöntemleri ile Analizi

Tablo 4. Kriterlerin Ağrrlkklarv ve En İyi / En Kötü F Değerleri

\begin{tabular}{|c|c|c|c|c|c|}
\hline Ă̈ırlık & Kriterler & Sosyal ve Ekonomik Değişkenler & $\begin{array}{l}\text { Min/ } \\
\text { Maks } \\
\end{array}$ & $F i^{*}$ & $F i^{-}$ \\
\hline \multirow{4}{*}{0,02506} & \multirow{4}{*}{$\begin{array}{l}\text { Demografi ve } \\
\text { Nüfus }\end{array}$} & Nüfus (bin) (2018) & Min & 275 & 5603 \\
\hline & & Nüfus Artış Hızı (2016) & Min & $-0,6$ & 2,2 \\
\hline & & Nüfus Yoğunluğu (km²/kişi) & Min & 3,69 & 135,57 \\
\hline & & Kentsel Nüfus Payı (\%) & Maks & 64,25 & 34,88 \\
\hline \multirow{2}{*}{0,0727} & \multirow{2}{*}{ İstihdam-İsssizlik } & Çalışan Sayısı/Aktif Ekonomik Nüfus & Maks & 0,947 & 0,73 \\
\hline & & İşsizlik Oranı & Min & 5,2 & 27 \\
\hline \multirow{2}{*}{0,11205} & \multirow{2}{*}{$\begin{array}{l}\text { Nüfusun Gelir ve } \\
\text { Giderleri }\end{array}$} & Kişi Başına Düşen Aylık Gelir & Maks & 33201 & 14766 \\
\hline & & Yoksulluk Oranı & Min & 10,9 & 35,1 \\
\hline \multirow{3}{*}{0,06688} & \multirow{3}{*}{ Sağlık } & Yaşam Beklentisi & Maks & 83,6 & 76,8 \\
\hline & & Bebek Ölümleri (1000 doğumda) & Min & 5,4 & 12 \\
\hline & & Doktor Sayısı (1000 kişi başına) & Maks & 6,5 & 2,7 \\
\hline \multirow{2}{*}{0,03852} & \multirow{2}{*}{ Eğitim-Formasyon } & Okul Öncesi Eğitim (çocuk) & Maks & 272382 & 11233 \\
\hline & & Yüksek Ö̆ğretim Öğrenci Sayısı & Maks & 117865 & 595 \\
\hline 0,03989 & Ücretli Servisler & Toplam Hizmet Hacmi Endeksi & Maks & 36453218 & 502677 \\
\hline 0,02506 & Yaşam Standartları & 1000 Kişi Başına Düşen Araba Sayısı & Maks & 315,1 & 163,6 \\
\hline \multirow{3}{*}{0,17449} & \multirow{3}{*}{ Milli Hasıla } & Brüt Bölgesel Ürün (milyon ruble) & Maks & 2015934702 & $5 \mathrm{E}+07$ \\
\hline & & Perakende Ciro $(\%)$ & Maks & 127,8 & 96 \\
\hline & & Kişi Başına Düşen GRP & Maks & 363731 & 106757 \\
\hline \multirow{4}{*}{0,17449} & \multirow{4}{*}{ Endüstriyel Üretim } & Sanayi Üretim Endeksi & Maks & 135,2 & 89,6 \\
\hline & & Maden Çıkarımı (\%) & Maks & 122,6 & 80,1 \\
\hline & & İmalat & Maks & 139,3 & 87,4 \\
\hline & & Elektrik Gaz ve Su Üretimi-Dağıtımı & Maks & 116,4 & 90,1 \\
\hline 0,06688 & Fiyatlar & Tüketici Fiyat Endeksi & Min & 2,25 & 5,33 \\
\hline \multirow{2}{*}{0,02506} & \multirow{2}{*}{ Yatırım-İnşaat } & Sabit Kiymet Yatırımlarının Hacmi & Maks & 111,8 & 65,4 \\
\hline & & Konut İnşaatı (bin metrekare) & Maks & 3579 & 59,2 \\
\hline 0,11205 & Diş Ticaret & Karşılama Oranı (İhracat/İthalat) & Maks & 148,4 & 0 \\
\hline \multirow{4}{*}{0,06688} & \multirow{4}{*}{ Tarım } & Tarımsal Üretim (\%) & Maks & 112 & 90,4 \\
\hline & & Hayvanc1lık Üretimi (\%) & Maks & 109,8 & 88,4 \\
\hline & & Mahsül Üretimi (\%) & Maks & 124,6 & 95,1 \\
\hline & & Büyükbaş ve Kümes Hayvancıllğ 1 & Maks & 502,2 & 9,8 \\
\hline
\end{tabular}

Tablo 5'te ise $S_{\mathrm{ij}}$, $\mathrm{Q}_{\mathrm{ij}}$ ve $\mathrm{R}_{\mathrm{ij}}$ değerlerinin sıralaması gösterilmiştir.

Tablo 5. Kriterlerin Ağrrlkklar ve En İyil En Kötü F Değerleri

\begin{tabular}{|c|c|c|c|c|c|c|}
\hline Bölge & $S_{i j}$ & $\boldsymbol{R}_{j}$ & $Q_{i}(v=0,5)$ & Siralama & $Q_{i}(v=0,7)$ & Siralama \\
\hline Kabartay - Balkar & 0,82434 & 0,09355 & 0,125 & 7 & 0,145 & 7 \\
\hline Karaçay - Çerkes & 0,81538 & 0,09163 & 0,109 & 8 & 0,132 & 8 \\
\hline İnguşetya & 0,65980 & 0,08691 & 0,000 & 10 & 0,000 & 10 \\
\hline Osetya & 0,78532 & 0,10223 & 0,154 & 6 & 0,146 & 6 \\
\hline Adigey & 1,36112 & 0,17449 & 0,872 & 3 & 0,821 & 3 \\
\hline Stavropol & 1,23967 & 0,09909 & 0,377 & 5 & 0,472 & 4 \\
\hline Krasnodar & 1,60221 & 0,17449 & 1,000 & 1 & 1,000 & 1 \\
\hline Çeçenya & 0,70748 & 0,09421 & 0,067 & 9 & 0,060 & 9 \\
\hline Dağıstan & 1,36898 & 0,17449 & 0,876 & 2 & 0,827 & 2 \\
\hline Kalmukya & 0,89016 & 0,14575 & 0,458 & 4 & 0,373 & 5 \\
\hline
\end{tabular}


Tablo 5’te gösterilen sonuçlar literatürde kabul görmüş iki koşula göre değerlendirilmiştir:

1. Kabul Edilebilir Avantaj Koşulu: En iyi ve en iyiye yakın iki alternatif arasında belirgin bir farkın olup olmadığını sorgulayan koşuldur.

$\mathrm{Q}_{2-} \mathrm{Q}_{1} \geq \mathrm{D}^{*} \mathrm{Q}$ ise kabul edilebilir avantaj koşulu sağlanmış olur.

$Q_{1}$ : Siralamada ilk sirada bulunan alternatifin $Q$ değeri

Q2: Siralamada ikinci sırada bulunan alternatifin Q değeri

$\mathrm{D} * \mathrm{Q}=\frac{1}{(j-1)} \quad$ (j:alternatif sayısi)

Yapılan sıralamada, v'nin her iki değeri için, Krasnodar, Dağıstan’a karşı kabul edilebilir avantaj koşulunu sağlamaktadır.

2. Kabul Edilebilir İstikerar Koşulu: Sıralamada, uzlaşık çözümün istikrarlı olduğunu savunabilmek için sağlanması beklenen koşuldur (Opricovic ve Tzeng, 2004, s. 448).

Bu koşula göre, en iyi $Q$ değerine sahip olan alternatifin $S_{i j}$ ve $R_{i j}$ değerlerinin en az bir tanesinin en iyi skora sahip olması gerekir. Sıralamada ilk sırada yer alan Krasnodar, en yüksek $R_{\mathrm{ij}}$ ve $S_{\mathrm{ij}}$ değerlerine sahip olduğundan bu koşulu sağlamaktadır.

6. Adıgey Cumburiyeti SWOT analizi: Tablo 5'e göre 1. ve 2. sirada yer alan Krasnodar ve Dağıstan halihazırda gelişmiş bölgeler olarak düşünülebilir. Adıgey Cumhuriyeti ise 3. sırada yer almasına rağmen inceleme sürecinde, sosyal yaşamının kalitesi ve ekonomik potansiyeli ile gelişime açık bir ülke olması bakımından dikkat çekmiştir. Sosyoekonomik potansiyeli değerlendirilebilirse bu bölgenin de ilk iki sıradaki bölgeler gibi gelişmiş duruma gelebileceği düşünülmektedir. Bu potansiyele dikkat çekmek, çalışmanın kazanımını arttırmak, sonuç ve önerileri zenginleştirilmek, çalışmayı geliştirmek isteyen araştırmacılara ve bu bölge üzerinde çalş̧mak isteyebilecek girişimcilere iş fikri oluşturabilmek için bölgenin ihtiyaçlarını, firsatlarını ve üstün ve zayıf yanlarını tanıtabilmek adına Tablo 6'da gösterildiği üzere SWOT (Strengths-Güçlü, Weaknesses-Zayıf, Opportunities-Fırsat, Threats-Tehdit) analizi yapılmıştır. SWOT analizi, bölgesel ekonomiler de dâhil olmak üzere herhangi bir karmaşık sistem için iyi bir değerlendirme yöntemidir.

Tablo 6. Adggey Cumburiyeti SWOT Analizi

\begin{tabular}{|c|c|}
\hline Güçlü Yanlar & Zayif Yanlar \\
\hline 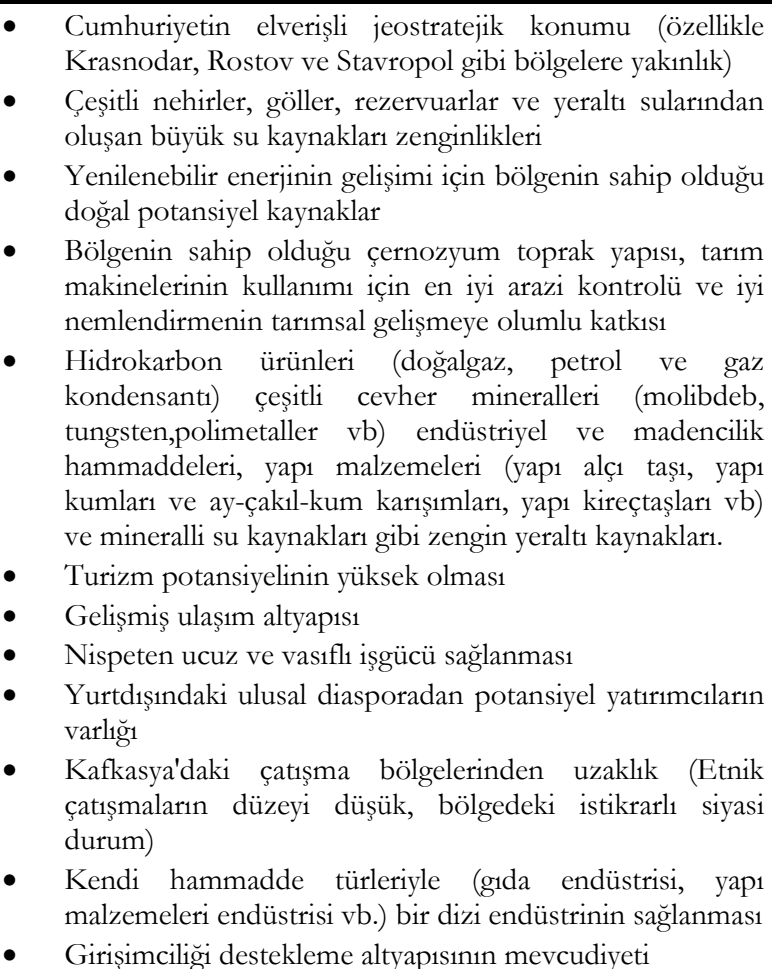 & 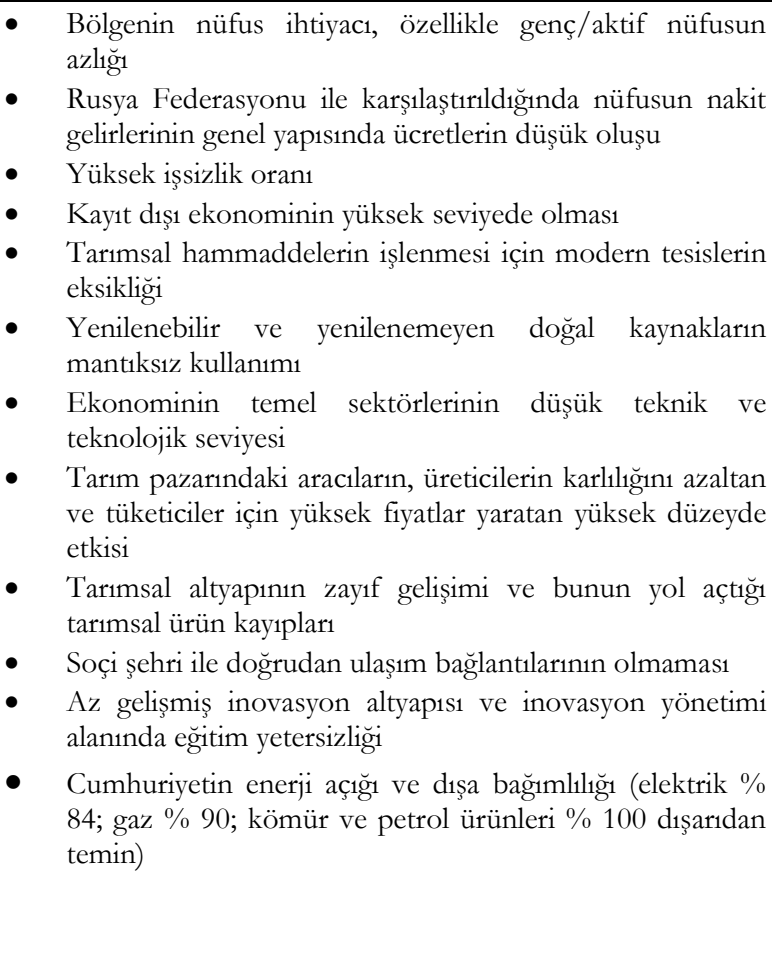 \\
\hline
\end{tabular}



\begin{tabular}{c}
\hline \multicolumn{1}{c}{ Firsatlar } \\
\hline - Çeşitli ulusal projelerle cumhuriyetin sosyoekonomik \\
durumunun geliştirilmesi
\end{tabular}

- Gelecek vaat eden yatırım projeleriyle girişimcilerin desteklenmesi, mali destek tedbirlerinin uygulanması ve projeleri uygulayan işletmelere vergi avantajı sağlanması

- Çocuk ölümlerinde azalma ve yaşam beklentisinde artış

- Eğlence ve turizm kompleksinin altyapısının geliştirilmesi ve iç pazarda turizm hizmetlerinin büyümesi

- Adıgey Cumhuriyeti ekonomisine yapılan yatırımın artışı

- Güney Federal Bölgesi'ndeki yapi malzemelerinin tüketimindeki artış nedeniyle, Adıgey Cumhuriyeti'nin mineral kaynak üssü temelinde inşaat endüstrisinin geliştirilmesi

- Çevre dostu ürünlerin üretimine yönelik teknolojilerin tanıtılmasıly çevre dostu ürünlere olan talebin artması ve tarımsal üretimdeki artış

- Bölgenin ekonomik olarak gelişmiş bölgelerdeki aktifliğini artırarak ürün satış pazarlarını genişletmesi

- Yeni hidroelektrik santralleri ve termik santralleri inşası ve alternatif enerji kaynakları üzerinde çalışan santrallerin ve mevcut tesislerin yeniden inşası

- Küçük ve orta ölçekli işletmelere destekler sağlanması ve gölge ekonomisinin payının azaltılması

\section{Tartışma, Sonuç ve Öneriler}

Çalışmada, Kuzey Kafkasya bölgeleri sosyoekonomik açıdan kümelenmiş ve sosyoekonomik gelişmişlikleri sıralanmıştır. Kümeleme analizine göre Kuzey Kafkasya bölgesinde, Krasnodar'n sosyal ve ekonomik açıdan en iyi; İnguşetya'nın ise zayıf değerlere sahip olmasından dolayı ayrı birer küme oluşturduğu, diğer bölgelerin ise birlikte kümelendiği görülmüştür. Sonrasında AHP yöntemi aracilığyla kriterlerin ağırlıkları hesaplanmış ve "Milli Hasıla", "Endüstriyel Üretim" ve "Dış Ticaret Faaliyetleri" kriterlerinin yüksek önem katsayılarına sahip olduğu belirlenmiştir. AHP yönteminden elde edilen ağırlıklar kullanılarak uygulanan VIKOR yönteminde, Dağıstan üzerinde kabul edilebilir avantaj düzeyi sağlayarak, her iki $v$ uzlaşma değeri için sosyoekonomik gelişmişlik düzeyi en yüksek olan bölgenin Krasnodar olduğunu görülmüştür (Tablo 5). İyimser yaklaşımla $(v=0,7)$ elde edilen sıralamada; Adıgey 3., Stavropol 4., Kalmukya 5., Kuzey Osetya 6., Kabartay - Balkar Cumhuriyeti 7., Karaçay - Çerkes Cumhuriyeti 8., Çeçenistan 9. ve İnguşetya 10. sırada yer almıştır. Uzlaşma değerinin formülasyonunda önem katsayılarının da dâhil edildiği verilerin toplamına daha çok ağırlık verilmesi, çalışma bütününü daha doğru ve gerçekçi temsil edeceğinden maksimum grup faydası $(v=0,7)$ değeri sonuçları yorumlamada esas alınmıştır.

Çalışma sırasında Adıgey Cumhuriyeti, sahip olduğu potansiyel bakımından araştırmacıların dikkatini çekmiştir. Bu nedenle Adıgey Cumhuriyeti'nin sosyoekonomik yapısı incelenerek çeşitli stratejilerle desteklemiştir. SWOT analizi ile Adıgey Cumhuriyeti’nin sahip olduğu kaynaklar, doğal özellikler, coğrafi konum, rekabet avantajları ve ana potansiyel firsatları göz önünde bulundurularak 2025 yllına kadar gerçekleştirilmesi hedeflenen çeşitli stratejik planlar oluşturulmuştur. Bu planlar ile yenilikçi bir kalkınma sürecinde ilerlemek, yeni bir ekonomik büyüme kalitesine geçiş için örgütsel ve yönetimsel temelleri oluşturmak, beşerî sermayenin geliştirilmesi, nüfusun yaşam standardının yükseltilmesi, ekonomik kalkınma için elverişli bir yatırım ortamının yaratılması hedeflenmiştir.

Adıgey Cumhuriyeti; sosyal yapı, endüstriyel üretim ve mühendislik altyapısına yatırılan kaynakların getirisini arttırmayı, bütçe harcamalarını optimize etmeyi, sosyoekonomik ve kültürel alanda yurtdışındaki temaslarını geliştirerek uluslararası iş birliklerini ilerletmeyi, yurt dışında ve Rusya Federasyonu içinde sergi ve fuar faaliyetlerini yoğunlaştırarak işletmelerinin ürünlerini tanıtmayı ve potansiyel ortaklarla buluşmayı hedeflemektedir. Ayrıca Rusya'da ve yurtdışında ihracata yönelik üretimin yaratılması için çeşitli yatırım kredileri, ihracat sonras1 finansman, uluslararası faktöring, akreditifler, yabanc1 alıcilara ve yabanc1 alıc1 bankalarına krediler sağlamak, dış pazarlara girmek isteyen girişimciler için ücretsiz seminerler ve ustalık kursları düzenlemeyi planlamaktadır. Eğitim ve kursların yanı sıra, girişimcilerin desteklenmesi için devlet teşviği ve destekleme altyapısının geliştirilmesi, çeşitli projeler yürütülmesi ve girişimcilerin haklarının korunması amaçlanmaktadır. Rusya Bilgi Teknolojilerini Geliştirme Fonu, dijital teknolojilere dayalı projelerin tamamlanması için de hibe desteği sağlamayı planlamaktadır. Bunlar arasında kuantum ve yeni 
üretim teknolojileri, robotik ve sensör bileşenleri, nöroteknolojiler ve yapay zekâ, dağıtılmış kayıt sistemleri ve kablosuz iletissim teknolojisi, sanal- artırılmış gerçeklik ve yerli yazılım geliştirme yer almaktadır. Küçük ve Orta Ölçekli İşletmeler (KOBI)'in gelişimi için oluşturulan hedeflerin arasında ise KOBI'lerin tercihli finansman da dâhil finansal kaynaklara erişiminin artırılması, iş yapma koşullarının iyileştirilmesi, çiftçileri desteklemek ve kırsal kalkınma için bir sistem oluşturulması, işletmelerin mühendislik altyapı tesislerine erişimini kolaylaştırılması, işletmelerin örgütsel desteği için önlemler sağlanması, idari engelleri azaltılması ve eğitim programlarının düzenlenmesi başta gelmektedir. Bölgenin sahip olduğu zengin kaynaklara rağmen kaynakların etkin kullanılamamasının sebep olduğu enerji açığı ve dışa bağımlılığı azaltmak için alternatif enerji kaynaklarına odaklanılmıştır. Güneş ve rüzgâr enerji santralleri kurulması, hidrotermal enerji santrallerinin ve elektrik santrallerinin geliştirilmesi, yeni yakıt ve enerji tesislerinin inşa edilmesi planlanmaktadır. İşletmelerin süreçlerini optimize etmek, maliyetlerini azaltmak, ürün kalitesini ve rekabet gücünü artırmak, işgücü verimliliğini ve istihdam desteklerini arttırmak Adıgey Cumhuriyeti’nin 2024 stratejik planları arasındadır. Üreticilerin modern üretim yöntemlerine teşvik edilip desteklenmesi ve yeni endüstrilerin oluşturulması hedeflenmektedir. Bölgenin hazırlandığ1 Uluslararası İş birliği ve İhracat projesinin temel unsurları arasında yer alan tarım ürünlerinin ihracatının hacminin arttırlması istenmektedir. Ana ürün grupları arasında; hayvansal veya bitkisel katı ve sıvıyağlar, süt ürünleri, tavuk yumurtaları, bal, alkollü ve alkolsüz içecekler, sebze ve meyvelerin işlenmiş ürünleri ve tahıl ürünleri yer almaktadır. Başlıca ticaret ortakları arasında, Abhazya, Özbekistan, Gürcistan, Ukrayna, Çin, Azerbaycan, Belarus önde gelir. Adıgey Cumhuriyeti, Türk girişimcilerle de iş ilişkilerini genişletmeye ilgi duyduklarını belirtmektedir. 2019 yllı Nisan ayında Adıgey Cumhuriyeti Başkanı Murat Kumpilov'un önderliğinde Adıgey Cumhuriyeti heyeti Türkiye'ye resmi bir ziyarette bulunmuş, burada cumhuriyetin yatırım ve ekonomik potansiyeli iş dünyasına sunulmuştur. 26 Şubat 2020 tarihinde de Maykop iş temsilcileri, Türkiye Cumhuriyeti'nden girişimciler heyeti tarafindan ziyaret edilmiştir. Adıgey'den 9 şirketin katıldığ bu ziyarette; pirinç, mısır tohumu, ayçiçek yağı, doğal kaplama üretimi, ağaç işleme ürünleri ve diğer çeşitli gıda ürünleri tedariği üzerine protokol imzalanmıştır. Dijital ekonomi alanında da gelişmek Adıgey Cumhuriyetinin stratejik hedeflerinden biridir. Daha rekabetçi ürünler geliştirmek, navlun lojistiğini iyileştirmek, ihracat desteklerini kuvvetlendirmek, turizm, eğitim, tıbbi ve diğer hizmetlerde ticaret geliştirmek bu hedefler arasındadır. Dijital ekonomi alanında eğitim merkezleri oluşturulması modern bir bilgi güvenliği sisteminin tanıtımı yapılması ve elektronik devlet altyapısının geliştirilmesi planlanmaktadır.

Sonuç olarak; yapılan çalısmada, Kuzey Kafkasya bölgeleri sosyoekonomik açıdan kümelenmiş ve sosyoekonomik gelişmişlikleri sıralanmıştır. Adıgey Cumhuriyeti'nin sosyoekonomik yapısı SWOT analizi yöntemiyle incelenerek çeşitli stratejiler sunulmuştur. İlerleyen çalışmalarda, bu çalışmaya benzer olarak başka bölgeler için de yeni öneriler ve stratejiler geliştirilebilir. Bölgelerin birbirleriyle etkileşimi göz önüne alınarak ortak stratejiler oluşturulabilir. Yapılan analizler ve sıralamalar, daha yeni veri tarihleri ve farklı yöntemlerle daha detaylı olarak incelenebilir. Çalışmada elde edilen sonuçlar doğrultusunda bölgeler üzerinde iyileştirmeler, yeni iş fikirleri ve girişimler düşünülebilir.

\section{Etik Beyan}

"Kuzey Kafkasya Sosyoekonomik Yapısmm Kümeleme ve Çok Kriterli Karar Verme Yöntemleri ile Analizị" başlıklı çalışmanın yazım sürecinde bilimsel kurallara, etik ve alıntı kurallarına uyulmuş; toplanan veriler üzerinde herhangi bir tahrifat yapilmamış ve bu çalışma herhangi başka bir akademik yayın ortamına değerlendirme için gönderilmemiştir. Bu araştırmada hazır veri seti kullanıldığ için etik kurul kararı zorunluluğu taşımamaktadır.

\section{Kaynakça}

Açma, B. ve Yenişen, K. (2013). Kafkasya'nın ekonomik potansiyeli ve dönüşümü için politika ve stratejiler. Yönetim ve Ekonomi: Celal Bayar Üniversitesi İktisadi ve İdari Bilimler Fakültesi Dergisi, 20(2), 131-149. Erişim adresi: https://dergipark.org.tr/tr/pub/yonveek/issue/13699/165820

Adigey Cumburiyeti Resmi Web Sitesi. (2020). http://www.adygheya.ru/

Amirova, E. A. (2015). Kuzey Kafkasya bölgesinin sosyoekonomik koşulları ve bölgelerin farklılıkları. Ekonomik Dönüsümün Bölgesel Sorunlar, 12(62), 160-165.

Ajans Kafkeas. (2008). https://www.timeturk.com/tr

Akinin, P., Akinina, V., Alimova, I., Viderker, N. ve Ter-Akopov, A. (2016). The priorities of socio-economic and financial development of the North Caucasus Federal district in the current geopolitical situation. International Journal of Economics and Financial Issues, 6(1S), 200-205

Ceçen Cumburiyeti Hükümeti Web Sitesi. (2020). http:/ / chechnya.gov.ru 
Dünya Veri Atlası. (2019). https://knoema.ru/

Fırat, M., Dikbaş, F., Koç, A. C. ve Güngör, M. (2012). K-ortalamalar yöntemi ile yıllık yağışların sınıflandırılması ve homojen bölgelerin belirlenmesi. IMO Teknik Dergisi, 383, 6037-6050. Erişim adresi: https://dergipark.org.tr/tr/pub/tekderg/issue/12746/155157

Fuat, B. (2015). Kuzey Kafkasya Cumburiyetleri. http://ajanskafkas.com/gorus/kuzey-kafkasya-cumhuriyetleri/

Gerasimov, A. N., Gromov, Y. I., Levchenko, S. A., Grigorieva, O. P. ve Oboturova, N. P. (2014). Features of the spatial socio-economic systems development in the North Caucasus Federal District. World Applied Sciences Journal, 29(5), 699-705

Gür, S.., Hamurcu, M. ve Eren, T. (2017). Ankara'da monoray projelerinin analitik hiyerarşi prosesi ve 0-1 hedef programlama yöntemleri ile seçimi. Pamukekale Üniversitesi Mühendislik Bilimleri Dergisi, 23(4), 437-443. doi: $10.5505 /$ pajes.2016.03903

Gürbüz, M. ve Karabulut, M. (2008). SSCB’nin dağılmasıyla bağımsızlı̆̆ına kavuşan ülkelerde ortalama yaşam süresi ile sosyo-ekonomik değişkenler arasındaki ilişkiler. Coğrafi Bilimler Dergisi, 6 (1), 69-83

Gürbüz, M. ve Karabulut, M. (2009). SSCB'nin dağılmasıyla bağımsızlığına kavuşan ülkelerde sosyo-ekonomik benzerlik analizi. Bilig Türk Dünyası Sosyal Bilimler Dergisi, 50, 31-50

Han, J., Kamber, M. ve Pei, J. (2011). Data mining concepts and techniques third edition. Elsevier.

Holland, E. C. (2016). Economic development and subsidies in the North Caucasus. Problems of Post-communism, 63(1), 50-61.

Kalmukya Cumburiyeti Hükümeti Web Sitesi. (2020). http:/ /www.kalmregion.ru/

Kafkas $\dot{I}_{s}$ Adamlar Derneği $(K A F \dot{L} A D)$. (2020). http://www.kafiad.org/alt/cecen.htm

Kafkeas Iss Adamlar Derneği (KAFLAD). (2020). http://www.kafiad.org/alt/dagis.htm

Kocalar, A. O., Üstün, Y. M. ve Alan, M. (2018). Nüfusu yok olmaya yüz tutmuş bir cumhuriyet: adigey. Marmara Cografya Dergisi, 37, 152-166.

Kolosov, V. A., Vendina, O. I., Gritsenko, A. A., Glezer, O. B., Zotova, M. V., Sebentsov, A. B., ve Panin, A. N. (2017). Economic and social reforms in the North Caucasus: Goals, limitations, problems, and results. Regional Research of Russia, 7(3), 259-270.

Kurey Kafkasya Bölgesi Devlet İstatistik. Servisi. (2019). https:// stavstat.gks.ru/

Larionova, A. A., Tyutyukina, E. B., Zaitseva, N. A., Danilov, A. I., Ushakova, E. O. ve Kunakovskaya, I. A. (2018). Investigation of the factors determining the investment potential of the tourist industry of the north caucasus. Revista ESPACIOS, 39(22), 1-6.

Lixin, D., Ying, L. ve Zhizuang, Z. (2008). Selection of logistics service provider based on analytic network process and vikor algorithm. ICNSC 2008- IEEE International Conference Proceedings, (s. 1207-1210). Sanya.

Magomedovich, S. G. (2017). Kuzey kafkasya federal bölgesinin iş gücü piyasasının oluşumu ve gelişiminin sosyoekonomik faktörleri. Bölgesel Ekonomik Dönüsüm Sorunlar Dergisi, 8(82), 48-54.

Mikail, E. H. (2016). Kalmukya Cumburiyeti. Turansam Stratejik Araştırmalar Merkezi: http:/ / www.turansam.org/makale.php?id=10219

Opricovic, S. ve Tzeng, G. H. (2004). Compromise solution by mcdm methods: a comparative analysis of vikor and topsis. European Journal of Operational Research, 156(2), 445-455.

Özbay, Ö. (1999). Dünden bugüne kuzey kafkasya. Ankara: Kafder.

Paksoy, S. (2015). Ülke göstergelerinin vikor yöntemi ile değerlendirilmesi. Ekonomik ve Sosya Araştırmalar Dergisi, 11(2), 153-169.

Sandal, E. K. (2009). Sosyo-ekonomik kriterler bakımından türkiye, doğu avrupa ve kafkas ülkelerinin karşılaştırılması. Doğu Coğrafya Dergisi, 14(22), 89-105.

Sennaroglu, B., ve Varlik Celebi, G. (2018). A military airport location selection by AHP integrated PROMETHEE and VIKOR methods. Transportation Research Part D: Transport and Environment, 59, 160-173.

Stavropol Tarm Bakanlı̆gr. (2020). http://www.mshsk.ru/

Sukhovskaya, D. N. (2013). Sustainable development of rural areas of the North Caucasus Federal District, based on the use of their socio-cultural and natural potential for the development of the agricultural and ecotourism. Наука и технологии, 1, 224-233.

Topçu, M. (2006). Karaçay-Çerkes (Özerk) Cumburiyetinin demografik yapısı (Yüksek Lisans Tezi). Marmara Üniversitesi, Sosyal Bilimler Enstitüsü, İstanbul.

Uyar, M. (2018). Dağıstan tarihinin Türk tarihi ile ilişkisi ve Dağıstan'ın Türkiye için önemi. Türk Dünyası Araştırmalar, $\quad 119$ (234), $\quad 217-234 . \quad$ Erişim $\quad$ adresi: https://www.idealonline.com.tr/IdealOnline/lookAtPublications/paperDetail.xhtml?uId=75659\&

Yanar, S. (2002). Türk-Rus Ilişskilerinde Giz̨li Güç Kafkasya. İstanbul: IQ Kültür Sanat Yayıncilık.

Yıldız, M. Ş., Kekezoğlu, B. ve İşen, E. (2019). K-ortalamalar kümeleme yöntemi ile güç transformatörlerinin bakım stratejilerinin belirlenmesi. Mühendislik. Bilimleri ve Tasarm Dergisi, 7(3), 505-513. doi: 10.21923/jesd.484899 


\section{EXTENDED ABSTRACT}

The North Caucasus has attracted attention throughout history with its location on important trade routes, cultural richness created by the people living on its territory and untainted natural beauty. In this study, we examined the socioeconomic structure of the North Caucasus region, which has an important geopolitical location, reserves and economic potential besides its geographical beauty and cultural richness. The North Caucasus Federal District consists of several units. Ten administrative units in the region were included in the study. These are Kabardino-Balkaria, Karachay Circassian, Chechnya, Dagestan, North Ossetia Ingushetia, Adygea, Kalmykia, Stavropol and Krasnodar. In the study, we aimed to present the socioeconomic map of the region to the entrepreneurs who want to invest in the region and to contribute to new business ideas that may arise. In line with this purpose, we determined the criteria that are indicative of the social and economic development levels of the regions and collected the data of the criteria. Socially determined criteria are "demography and population", "employment-unemployment", "health", "education-formation", "paid services" and "living standards". The economically determined criteria are "gross regional product", "population income and expenses", "industrial production", "prices", "investment-construction", "foreign trade" and "agriculture".

Cluster analysis is a multivariate statistical method used for classifying data according to their similarities and subdividing them. The K-Means method is one of the most commonly used among nonhierarchical clustering methods. In the study, we divided the region into 3 clusters with the K-means cluster analysis using the 30 variables we examined under the 13 criteria listed above. Thus, we observed the similarities of the socioeconomic behavior of the regions. Krasnodar and Ingushetia created a separate cluster. Other regions were clustered together. When we examine the cluster structures, we can say that Krasnodar is the best socially and economically and the weakest in Ingushetia. In addition, the most effective variables in the formation of cluster groups were determined as gross regional product, infant mortality and housing construction.

Analytical Hierarchy Process (AHP) is a Multi-Criteria Decision Making (MCDM) method that enables comparison of numerical and non-numerical criteria and analytical evaluation of alternatives. In the second part of the study, we calculated the weights of the criteria using the AHP method. We determined that the most important factors affecting socioeconomic development are "industrial production" and "national product" with a $17 \%$ share.

The VIKOR method is one of the MCDM methods that helps to choose the closest and most compromised alternative to the targeted outcome among the alternatives based on multiple criteria. When applying the VIKOR method, we used the criteria weights obtained from the AHP method. As a result, we determined that the region with the highest socioeconomic development level is Krasnodar. In the ranking obtained with an optimistic approach, Dagestan ranked 2nd, Adygey 3rd, Stavropol 4th, Kalmykia 5th, North Ossetia 6th, Kabardino- Balkaria Republic 7th, Karachay Circassian Republic 8th, Chechnya 9th and Ingushetia 10th. It is remarkable that Krasnodar, the leading region of the North Caucasus, in terms of industrial production activity and economic development, has formed a single cluster as the most developed region in cluster analysis and ranked first in the VIKOR ranking.

During the study, the Republic of Adygea attracted our attention with the quality of social life, its economic potential and being a country open to development. For this reason, in addition to the findings of the study, the Republic of Adygea was closely introduced in order to increase the gain of the study, enrich the results and suggestions and to give business ideas to entrepreneurs who may want to work on this region. In order to introduce the needs, opportunities and superiorities of the region, the socioeconomic situation of the Adygea Republic was analyzed by SWOT (Strengths-WeaknessesOpportunities-Threats) analysis and the results were supported by various strategies. The Republic of Adygea aims to increase the return of resources invested in social structure, industrial production and engineering infrastructure, optimize budget expenditures, improve international cooperation by improving socioeconomic and cultural contacts abroad, promote the products of its enterprises and meet with potential partners. It also plans to organize free seminars and master classes for entrepreneurs who want to enter foreign markets, provide various investment credits, post-export financing, international factoring, letters of credit, loans to foreign buyers and foreign buyer banks for the creation of exportoriented production in Russia and abroad. It is planned to establish solar and wind power plants, develop hydrothermal power plants and power plants, and build new fuel and energy facilities. Optimizing the processes of enterprises, reducing their costs, increasing product quality and competitiveness, increasing 
labor productivity and employment support are among the country's 2024 strategic plans. All these listed make the country an important investment area.

In future studies, similar to this study, new recommendations and strategies may be developed for other regions. Common strategies can be created by considering the interaction of regions with each other. The analyzes and rankings made can be examined in more detail with newer data dates and different methods. In line with the results obtained in the study, improvements on the regions, new business ideas and initiatives can be considered. 